no clear distinction between science and technology and many famous men exemplified the union of the two in their own work. The distinction began to be emphasized in the nineteenth century but now it was growing out of date again; advances could come from either direction-the demand for a prettier stocking might lead to new theories of molecular structure or the new theories might lead to now fabrics. He congratulated the students of the College on having chosen a scientific career at this exciting period of expansion and emphasized the great possibilities that lay before them.

After declaring the extensions open, Lord Adrian inspected the new buildings, and the whole of the College was thrown open to visitors.

N. M. H. LightFoot

\title{
ADMISSION OF STUDENTS TO UNIVERSITIES
}

\begin{abstract}
$\mathrm{O}$ E of the most notable contributions in the report* of the vice-chancellor of the University of Birmingham for 1958 is his account of admissions procedure. Students are chosen by the faculty admission tutors in consultation with the heads of departments. The process goes on from January every year (or earlier) until September. Applications come from all over Britain, and from overseas, in numbers far exceeding the available places. Many are from candidates simultaneously applying to other universities as well, often with a preference for Oxford or Cambridge. They furnish school records, and headmasters' and headmistresses' assessments; many of them are brought to the universities for interview. More often than not the crucial information about applicants, namely, their performance in the ' $A$ ' level examinations for the General Certificate of Education, is not available until mid-August, but it is impracticable to leave all decisions until that late date. Tentatively, at least, the university must make most of its choice before then, while the candidate also wants to exercise his choice among universities. The result is that a complicated and haphazard system of provisional offers of admission has grown up, in which the universities compete for what they think are good candidates and the candidates compete for what they think are good universities. The universities often keep the candidates on tenterhooks and the candidates sometimes treat the universities in cavalier fashion.
\end{abstract}

* University of Birmingham. Report of the Vice-Chancellor and Principal for the Calendar Year 1958. Pp. 26. (Birmingham: The University, 1959.
The position has grown worse in the past three years, and threatens to grow worse still as numbers and competition increase. No smooth and tidy system seems possible so long as General Certificate examinations are held in June and university sessions begin in Oetober ; if those events were to be separated by a longer interval of time, no one can think how to occupy the boys and girls during that interval, short of imposing some kind of civilian national service. In studying the difficulty, however, the Committee of Vice-Chancellors and Principals concluded that it could at least be mitigated, and in June 1958 the Committee made a series of recom. mendations to the universities (other than Oxford and Cambridge) designed to smooth the path of university applicants to a considerable extent. It asked, among other things, that application forms should be simplified and made more nearly uniform ; that heads of schools should be invited to use a common form for reports on candidates; that application and acceptance fees, and special entrance examinations, should be abolished; that closing dates for the receipt of normal applications by all universities should be synchronized; that provisional offers of places should state the conditions in specific terms ; that candidates should be informed as promptly as possible where they stand, and be allowed reasonable time in which to accept or decline places offered to them. Birmingham has accepted these recommendations and is giving effect to them in 1959. If all universities do the same there is likely to be a substantial improvement in an inherently difficult situation.

\section{DIRECTORY OF NATURAL HISTORY AND OTHER FIELD STUDIES}

$\mathrm{O}$ behalf of the Carnegie United Kingdom Trust, the British Association for the Advancement of Seience has performed a useful service to many people in compiling a directory of natural history and other field societies.

The response to 4,000 individual inquiries made by Dr. Averil Lysaght showed that some eight hundred natural history societies flourish in Great Britain to-day. These he carefully listed and provided with a geographical index so that their work may be better known and co-ordination between them facilitated.

The publication of the Directory, so shortly after the formation of the Council for Nature, reflects the increased interest in natural history. As a comprehensive work of reference, it has attempted to include all professional and amateur societies in England, Scotland, Wales and Northern Ireland which are concerned in any way with field studies (a term which provides an umbrella for a multitude of sub- jects from interplanetary exploration to guppybreeding), or which, while not taking part in field work themselves, are active in publishing the results of such work. Medical societies have not been included, nor have societies devoted to horticulture, agriculture and forestry, nor those concerned with plants or animals purely for sporting or commercial purposes. School societies have only been listed if they publish some record of their work or carry out some special studies; it is impressive to note how many do fulfil these qualifications.

Of the societies listed, those which claim to be specifically concerned with natural history and field studies form the majority, with archrology and local history making a close second. A considerable number-somewhere about 10 per cent-are occupied with the preservation of the countryside in the broadest sense. Astronomy and meteorology are combined in a single section; geology has a section 
to itself, though many geologists must be numbered among the members of the geographical societies listed in the general section. Bird-watching and ornithology prove the most popular single subject, and the Directory reflects the growth of new types of society, such as the various spelæological societies engaged in surveying and excavating cave systems in Great Britain; the underwater swimming clubs, many of which are turning from sporting and hunting activities to the study of freshwater and marine life, as well as the development over recent years of the county naturalists' trusts.
There is a strongly local flavour to a high proportion of the societies. Life membership thrives in Scotland and diminishes with decreasing latitude; after London, Yorkshire boasts the largest concentration of societies; Lincolnshire can claim the second oldest in England (ranking next to the Royal Society), which numbered among its members Newton, Addison and Pope. Glamorgan holds the monopoly in the study of lichens, while underwater swimmers are as bold in the north and midlands as in the south. The geographical index provides an easy guide to the regional distribution.

\section{PROPERTIES OF A RECEPTOR MEMBRANE}

\section{From THE DEPARTMENT OF PHYSIOLOGY, COLUMBIA UNIVERSITY, COLLEGE OF PHYSICIANS AND SURGEONS, NEW YORK}

\section{Spatial Summation of Electric Activity in a Non-myelinated Nerve Ending}

ATER removal of most of the non-nervous A (capsular) tissue of a Pacinian corpuscle, the sense organ's remains, consisting mainly of a nonmyelinated ending, continue to be as mechanosensitive as the intact sense organ : the ending produces generator potentials in response to mechanical stimuli of the same order of magnitude as the intact corpuscle ${ }^{1}$. This decapsulated preparation offers the opportunity to study the properties of a non-myelin. ated nerve ending in isolation. The ending is accessible for micro-electrode recording, and visually selected portions of ending can be stimulated mechanically with a crystal-driven stylus. The ending is straight and long (about 600u); two separate regions of ending can be stimulated simultaneously with two independently driven styli.

When a mechanical stimulus is applied to a portion of ending by one stylus alone, an active response (depolarization) is $\mathrm{de}$ tected at that region. This response is confined to the region of ending which has been stimulated mechanically, but does not propagate actively along nonstimulated portions of ending. Fig. 1 illustrates an experiment in which two micro-electrodes are placed in contact with the ending. A weak mechanical stimulus is delivered to a portion of ending close to electrode $E_{1}$. This causes depolarization of a region of membrane in the vicinity of the stimulating stylus which is recorded by electrode $E_{1}$. Electrode $E_{2}$, about $500 \mu$ apart, still detects this response, but the peak amplitude and the rate of rise of the response are markedly reduced. By systematic scanning of the ending's surface with a micro-electrode, the amplitude of the response is found to decrease exponentially with the distance from the stimulated region.

From the preceding results spatial summation of electric activity of independently active membrane regions ${ }^{2}$ emerges as a possible mechanism to account for the well-known increase in generator potential as a function of the strength of stimulus. It was, in fact, found that the depolarization of one membrane region adds up with the depolarization of another region. In the experiment illustrated in Fig. 2 the styli of two independent crystals were each applied to a

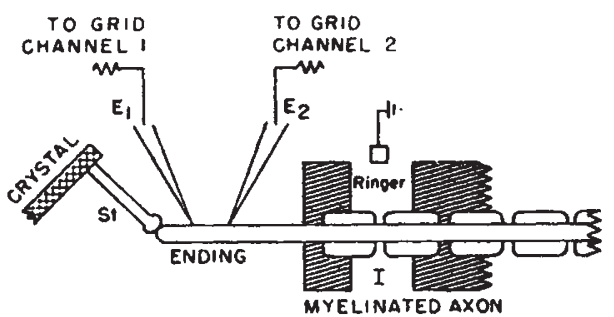

Fig. 1. Local activity confined to a small membrane portion of ending. Two microelectrodes $\left(E_{1}, E_{2}\right)$ connected to separate amplifler channels are placed in contact with the non-myelinated ending of a decapsulated Pacinian corpuscle. The preparation is pulled into a device which insulates the flrst node of Ranvier in contact with a common ground electrode from the ending. $E$, is placed at a distance of approximately $20 \mu$, and $E$, at approximately $520 \mu$ distance from the stimulating stylus (St). Beams 1 and 2 give the responses to a single mechanical stimulus as recorded by electrodes $E_{1}$ and $E_{2}$. respectively. Calibration: 50 \% Y.; 1 mser.
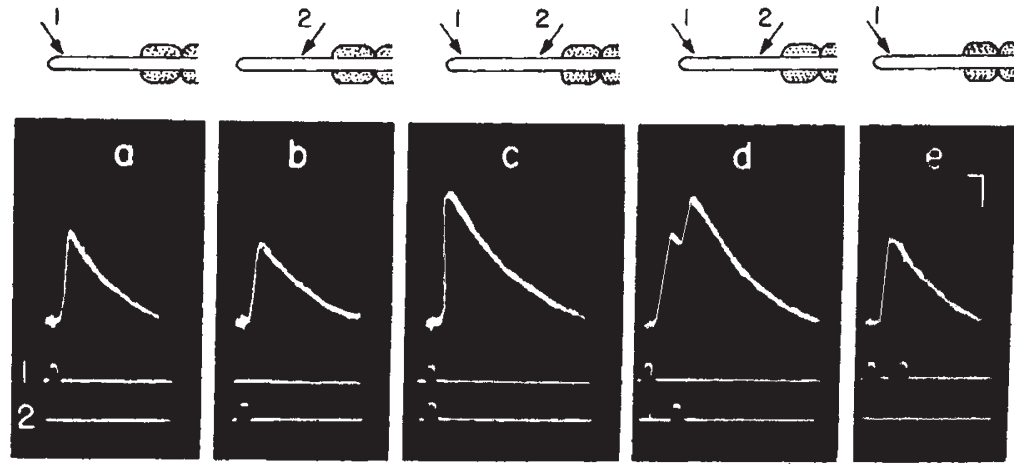

Fig. 2. Spatial summation of generator potentials in a single nerve ending. Styli 1 and 2 belong to independent stimulating crystals which deliver stimuli to two separate regions 2 belong to independent stimulating crystals which deliver stimuli to two separate region beam for generator potentials as recorded at the myelinated axon. $a$, stylus 1 alone delivers one stimulus; $b$, stylus 2 alone delivers one stimulus; $c$, styli 1 and 2 deliver delivers one stum simultaneously; $d$ stylus 2 applies a stimulus $i$ msec delayed from that of stylus $1 ;$ e, stylus 1 alone delivers two stimuli succeeding each other at a delay of 1 msec. Calibration : 1 msec. : $50 \mu \mathrm{V}$. 